\title{
Microinclusions in megagarnets: throndjemitic melt preserved in garnets at Gore Mountain, Adirondacks (US)
}

\author{
SILVIO FERRERO ${ }^{1}$, IRIS WANNHOFF ${ }^{2}$, OSCAR \\ LAURENT $^{3}$, CHRIS YAKYMCHUK ${ }^{4}$, ROBERT DARLING ${ }^{5}$, \\ BERND WUNDER $^{6}$, ALESSIA BORGHINI ${ }^{1}$ AND PATRICK \\ J. O'BRIEN ${ }^{1}$ \\ ${ }^{1}$ Universität Potsdam \\ ${ }^{2}$ Freie Universität \\ ${ }^{3}$ CNRS-Géosciences Environnement Toulouse \\ ${ }^{4}$ University of Waterloo \\ ${ }^{5}$ SUNY College at Cortland \\ ${ }^{6}$ GFZ, German Research Centre for Geosciences \\ Presenting Author: silv.ferrero@gmail.com
}

The garnet megacrysts (Fig. 1a) of Gore Mountain (Adirondacks, US) are world-renown crystals due to their size, up to $1 \mathrm{~m}$ in historical record, which makes them the largest known garnets on the planet. We show here that they are also host to the first primary inclusions of trondhjemitic melt found in natural mafic rocks (Fig. 1b). The petrological and experimental investigation of the inclusions, coupled with phase equilibrium modelling, shows that this melt is the result of $\mathrm{H}_{2} \mathrm{O}$-fluxed partial melting at $\mathrm{T}>900{ }^{\circ} \mathrm{C}$ of a lower crustal gabbro.

The compositional similarity between the trondhjemitic melt inclusions and tonalitic-trondhjemitic-granodioritic (TTGs) melts makes these inclusions the first direct natural evidence that melting of mafic rocks generates TTG-like melts, and provide us with the possibility to clarify processes responsible for the formation of the early continental crust (Fig. 1c). These TTG embryos represent the trondhjemitic end-member of the melts whose emplacement at upper crustal levels, after being modified by mixing and crystallization-related processes, leads to the formation of the TTG terranes. Our study also shows how the melt from $\mathrm{H}_{2} \mathrm{O}$-fluxed melting of mafic lower crust has mismatched mineralogical features as well as major and trace element signatures, previously interpreted as evidence of melting at very different pressures. This poses serious limitations to the established use of some chemical features to identify the geodynamic settings (e.g. subduction versus thickened crust) responsible for TTG generation and the growth of early crust.
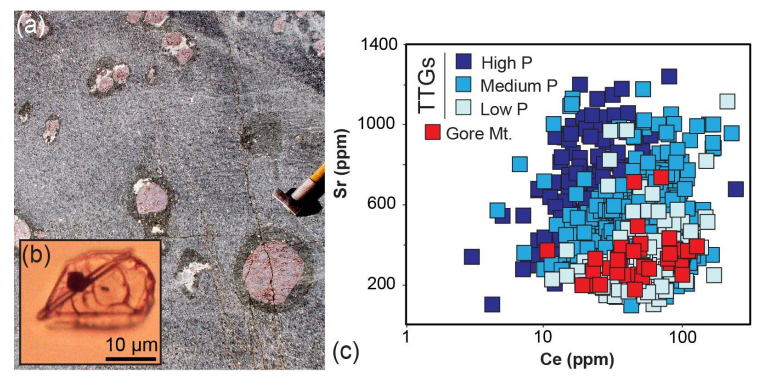